\title{
Performing, Passing, and Covering Motherhood in Academic Spaces: A Heartful Autoethnography
}

\author{
Anna S. CohenMiller
}

\begin{abstract}
This study applies heartful autoethnography to demonstrate the performance of being a mother in academia. As such, the article addresses (1) motherhood versus mothering, (2) the concepts of presentation of self, passing, and covering, (3) systematic bias mothers face in academic spaces, and (4) the ultimate costs of covering motherhood in academia.
\end{abstract}

\section{The Performance of an Academic}

While parents, in general, face challenges while working, mothers face additional constraining structures and stereotypes. For example, in Western contexts, when women become identified as mothers, their prestige and ability are questioned, termed a "maternal wall" (Williams, 2005). In this way, women can face multiple external structures impeding their success, such as "glass ceilings" limiting them from reaching top positions, "sticky floors" constricting their promotion, and then as a mother, a "maternal wall." In other words, performing the gendered role (Butler, 1993) of motherhood, or being considered as a mother, can be considered detrimental to one's work-life. In this performance, mothers in academia are consistently either evidencing expected ways of enacting their role of mother or challenging norms.

In this article, I reflect on being an academic and mother abroad. I note my move from academic life in the United States to Kazakhstan, Central Asia, providing context for the country, city, and University-life. Drawing from the "presentation of self" theory (Goffman, 1959), I show how being a mother in academia is a multifaceted performance. While I focus on mothers within the realm of academia (higher education), it should be recognized that mothers in other environments face similar and often more challenging workplaces. In negotiating the place of women in academia, mothers face a varying level of acceptance and disapproval, as well as a sense of being policed in their actions and choices. Throughout the following sections, I intersperse literature on motherhood and mothering, passing and covering with firstperson vignettes inspired by heartful autoethnography (Ellis, 1999). The process of developing such reflections highlights the process and product of autoethnography as a research method (Ellis, Adams, \& Bochner, 2010).

\section{Kazakhstani Context}

I live in Kazakhstan in Central Asia. Geographically, it is a vast country - the largest landlocked nation in the world - at about twice the size of Europe. Its borders include Russia to the north, China to the east, and Uzbekistan, Kyrgyzstan, and Turkmenistan on the south and west. Historically, the nation developed 
from a variety of nomadic clans, creating the cultures and linguistic traditions of a multiethnic, plurilingual society. Also, the country went through years of rule under the Soviet Union. In 1991, Kazakhstan emerged as an independent nation and until 2019 remained under the leadership of the first President. Today, the country has approximately 18 million people with the majority of people identifying as ethnic Kazakh (Pariona, n.d.). It is a secular Muslim state, has significant oil and agricultural wealth, and is frequently designated internationally as an "emerging economy."

With the size of the country, each region has varied weather, geography, traditions, and linguistic practices. Broadly, the southern area has mountains and steppe predominates the northern area. The capital of the country is in the north and this is where I live. The city sits on the Kazakh steppe and frequently experiences six months of snowy winters with high winds bringing the temperature to -40 $\mathrm{F}$ (or -40 C). The city is young, officially becoming the capital in 1997 (History of the City, 2020). Thus, the majority of people who live in the capital were raised in other regions. Construction is continual. Cranes spread throughout the city, with unique buildings scattered everywhere (e.g., the largest tent in the world; a large glass pyramid). As the capital city grew, many businesses and governmental centers moved from the former capital of Almaty to what has become known as Nur-Sultan (formerly Astana and Akmola). For example, the national opera, ballet, and many international embassies all moved to the new capital, drawing a growing population of close to a million people (Kazakhstan Population 2020). In the last few years, as the city has increased, so too has the international population, drawing employees and families to work at the major economic centers, embassies, and educational institutions.

\section{Education in Kazakhstan and The University Context}

Within the last 15 years, the Kazakhstani government has implemented major educational reforms. For example, in 2008, in collaboration with Cambridge University (UK), a new set of schools was introduced, emphasizing gifted education. These schools, termed the Nazarbayev Intellectual Schools (NIS), became the first schools in the country with tenets of autonomy and academic freedom (Shamshidinova, Ayubayeva, \& Bridges, 2014). During a similar timeframe, the Kazakhstani government developed the first autonomous university in the nation (About us, 2020). Named after the First President (Nazarbayev) and placed in the relocated capital city, Nazarbayev University (NU) opened in 2010. Each of the Schools within the University is partnered with a top international university. For example, the school I work with, the Graduate School of Education (GSE), is partnered with Cambridge University and the University of Pennsylvania. The first set of doctoral students were from Education. It was exciting to see them walk the stage in 2017, shaking hands with the President of Kazakhstan and representing pride for our School, the University, and representing the achievements of the country.

While the vast majority of students in the university are Kazakhstani citizens, the faculty is predominantly from top international universities. In Education, my colleagues and I have multicultural backgrounds working and living in a wide array of countries, including the United States and Canada, Europe, Africa, and throughout Asia. Across the University, there is a similar multicultural background, with degrees in education, humanities and social sciences, engineering and robotics, mining, and medicine. There are 
close to 5,000 students across the university with a 50/50 split between women and men (NU At a Glance). Women hold the majority of junior faculty positions with more senior positions held by men.

I present the context of Kazakhstan and University-life on campus, not to suggest this is the only place where these experiences result. Instead, I provide these backgrounds to demonstrate a basis for understanding how, in whichever context the academic lives, the considerations of how to behave, to perform, are frequently exacerbated by being a mother. The Kazakhstani history has led to a nation with a mixture of practices informed by traditional family cultures along with a more collectivist structure that affects the educational landscape. For example, young women typically feel pressure from their family and society regarding cultural expectations. These can include an emphasis on getting married by age 25, moving in with her in-laws, and having children. Having a son is important, as common practice suggests the youngest boy in the family is responsible for the parents as they age. Additional expectations frequently include looking aesthetically beautiful, being well educated, and having good employment. Considering that most young people are married with children by age 25 , the majority of graduate students have families.

Some women, especially those coming from more traditional Kazakh backgrounds in the southern areas of the country, are expected to take care of their children, house, in-laws, and cooking, while they pursue a desire to complete a degree (CohenMiller, Saniyazova, \& Saniyazova, 2019). Despite the modern views and traditions that many families follow in Kazakhstan, there are families who see women as wife and mother first (especially her in-laws), thus expecting she performs well in this role regardless of her other roles (Saniyazova, CohenMiller, \& Saniyazova, 2020).

The resultant pressure is immense for graduate student mothers to fit what it means to be a mother and woman in the Kazakhstani context, as well as to align with the varied perspectives of an international faculty. With such a multicultural faculty, there are varied perspectives on educational practice and our students' lives. Additionally, these expectations can be transferred to our perspectives of one another in terms of how to conduct research, teach, mentor, and also parent.

Academic life at an international university in Kazakhstan. When I meet friends from the United States, they ask me about living abroad in Kazakhstan. The simplest way to describe life in Kazakhstan and at the University is "easy." The low cost of living makes life much easier than when I lived in the United States. For example, the cost of a 20-minute taxi ride across town is about two dollars, USD. Likewise, hiring someone to clean a two-bedroom apartment costs about \$12 USD. And, a three-course lunch oncampus costs about four dollars USD. These example costs are highest in the capital city where I live. Since I see these prices as affordable, it makes working full-time away from the country of our origin (hence, away from the family support we once had), and living on campus with children, manageable. For example, it means I don't need to own and maintain a car. Instead, I can easily use a taxi when needed. Likewise, instead of having to focus tremendous energy on household upkeep, I can affordably hire someone to clean. 
When I first moved to campus, many buildings were still under construction and there were few businesses or resources. Over the years, there has been a significant expansion of opportunities and resources on campus for students and families. For instance, family-friendliness has been shown as relevant for recruiting and retention of faculty with families (Villablanca, Beckett, Nettiksimmons, \& Howell, 2011). Today, there is an expanding set of family-friendly resources. For example, I worked with the administration and community to implement an English-language Montessori-school and the first large-scale indoor playing room (Playing Room Opening Ceremony, 2020), the latter particularly important for long winters.

\section{Methodology}

For this work, I chose to use autoethnography to present an insider's perspective on my experiences of being a mother in academia, including a move to Kazakhstan from the United States with two young children. As a methodology, autoethnography stems from the anthropological tradition of ethnography. The detailed, in-depth engagement with participants can allow ethnographers to get a sense of the "livedexperience" of individuals and communities. For autoethnography, there is likewise an in-depth process of uncovering experience. Instead of looking outside ourselves to other participants and communities, the autoethnographer looks at him or herself. Carolyn Ellis, Tony Adams, and Arthur Bochner (2010) describe autoethnography as an integration of methods, "A researcher uses tenets of autobiography and ethnography to do and write autoethnography. Thus, as a method, autoethnography is both process and product" (para 1). Within autoethnography, there are various types, including evocative approaches that draw in the reader to the feelings and thoughts of the experience (Ellis \& Bochner, 2016).

In heartful autoethnography, Ellis (1999) calls for ethnography that delves intrinsically within the individual to engage and encourage feeling and thought from others, "...an ethnography that includes researchers' vulnerable selves, emotions, bodies, and spirits; produces evocative stories that create the effect of reality" (p. 66). As Ellis notes, heartful ethnography "...is concerned with moral, ethical, and political consequences; encourages compassion and empathy; helps us know how to live and cope (p. 669)." For this study, I found heartful autoethnography (Ellis, 1999, emphasis in original) as a means to speak to, about, and within the topic of being a mother in academia, while encouraging and seeking to help others.

Data involved memory-work, writing down stories of my experiences, reading them to others, rewriting, and reflecting again on the experiences. The process was iterative as I saw the importance to reframe or further articulate the experiences after sharing with others (e.g., scholars in motherhood in academia, scholars without a specialty in the topic, those with insider perspectives-my husband). The following stories are at times composite descriptions and include quotes reflecting the experience in general, instead of verbatim transcriptions. 


\section{Act I: When Fine Isn't Good}

I first met the Dean of my department through a video conference call when I was in the United States and he was in Kazakhstan. Now, I'm standing in front of him. I'm in both a new university and a new country, thousands of miles away from where I grew up. We sit across from one another. He sat behind his expansive wooden desk. I sat on the other. The Dean smiled frequently and welcomed me to the School. I took in the cavernous size of the office-sofa, bookcases, conference table, Persian rug. The light was streaming in through the large windows. I noticed details on the desk, my eyes landing on the stand holding business cards and pens.

I don't remember the details of what I wore that day, but I know I dressed in "professional" attire, using a high level of care. I felt put together and capable.

He chatted easily, asking questions about my move from the United States to Kazakhstan, "How has your transition been?" I answer quickly, trying to demonstrate confidence, "Good!"

I intentionally avoid talking about my children. The three-and-a-half-year-old, who was excited to travel in four airplanes, hasn't yet realized his friends won't be close by anymore. And the five-month-old has been attached to me nonstop throughout the trip, sitting comfortably in a tricolored Peruvian wrap. What will she do when I'm at work now?

In the interaction with the Dean, I skipped mentioning my family at all. I skipped it even though it was the entire reason I postponed starting the position for six months when my daughter was born. "Everything's fine!"

\section{Motherhood and Mothering}

Cultural expectations of mothers vary by nation and community. When becoming a mother, cultural expectations are placed on the person, determining how they are expected to behave. These expectations frame what Adrienne Rich (1976) refers to as the "institution" of motherhood. In the United States, for instance, 24/7 attention to the needs of children is expected of mothers. It is an "intensive mothering" model imposed on women to demonstrate themselves as good mothers (Hays, 1996). This conflicts with the competing expectation that American mothers will also have a workplace career outside of the home. Motherhood can then be considered as a "performance," one that Amber Kinser, Kryn Freehling-Burton, and Terri Hawkes (2014) note is consistently under scrutiny by others. In other words, mothers are expected to perform consistently. Tennely Vik and Jocelyn DeGroot (2019) explain it as a pressure mothers feel to be "flawless," or maintain a particular presentation, in public spaces. Therefore, for

mothers who work and live in the same general space, there would be a persistent pressure to perform in both roles. In this way, there is a complexity and challenge of living on campus, as the majority of places are public spaces.

In contrast to motherhood, the term "mothering" refers to taking care of or nurturing of another person. As Andrea O'Reilly (2017) explains, the act of mothering can be empowering. In this way, mothering 
can move beyond the cultural expectations and impositions placed upon mothers. Nevertheless, women still face concern about telling others about a pregnancy (Modern Family Index 2018). Mothers in the workplace face a "motherhood penalty" and "maternal wall" regarding hiring and promotion. A recent five-year study of women's work-life roles in four countries (United States, Germany, Italy, Sweden) found a "work-life crisis" for many, highlighted by the sharpest contradiction between work and family for women in the United States (Collins, 2019). By being a mother, women face a contradiction in being an ideal worker. By not focusing on their job without distraction, mothers no longer fit the "ideal worker norm" (Acker, 1990). In the academic workplace, parents, and mothers, in particular, can frequently be judged against this norm (Sallee, Ward, \& Wolf-Wendel, 2016). In order to address such bias, Shelley Correll (2013) notes the importance of altering the culture of work from one emphasizing an ideal worker and "the gendered norms about caretaking and breadwinning" (p. 6).

The idea of bringing children to campus went against what I had studied about being a mother and an academic (CohenMiller, 2013). For years, I had researched and uncovered stories about how women in academia face structural constraints, especially when becoming mothers in the United States. I knew how it is commonly recognized that women in the workplace face bias and gender stereotypes, which, for instance, can lead to a lower salary than their male counterparts. Some suggest "leaning in" (Sandberg, 2013). Yet, these messages can have negative consequences: "self-improvement messages intended to empower women to take charge of gender inequality may also yield potentially harmful societal beliefs" (Kim, Fitzsimons, \& Kay, p. 974). These lean in messages can affect all workplaces, including academia. Whether useful or detrimental, the advice and intended support abound (see Coming Out as Academic Mothers, Birken \& Borelli, 2014; Academia and Motherhood: How Can We Have it All, White, 2016, or The Mother-Scholars' Work-Life Integration, CohenMiller, 2016b).

\section{Act II: Bringing the Kids and Milk}

It was about $2 \mathrm{pm}$ in the afternoon. I left my office, walking through a shared space in the department. It was there I met the Vice-Dean who quickly came up to me. She was a European, energetic woman who created a community-feel for faculty and staff, with events such as a Friday tea-time and small presents from her travels.

She exclaimed, "Where are your kids?!" and added, "I can't wait to meet them! Bring them by any time." This was not what I was expecting in the academic workplace or what I had experienced previously. Such warmth and encouragement about family. Was this real? Did she really want me to bring them, or was she just being nice? Maybe I could parade them by the office, as long as I had a clear plan to move them back out, too? I was indeed welcomed by the leadership in this manner. Flashing back to my time in the United States, I recall hearing judgments about mothers in academia. People would talk about which mother "chose" the right or wrong time to have a child. One graduate student eagerly bounded to her advisor's office with "great news" to share about her thesis. But the advisor didn't feel the same enthusiasm. Instead, she looked up from her desk and asked sternly, "you better not say you're pregnant?" While the stories of graduate students reflect a different context, the experiences of academic mothers 
across institutions and levels show systematic challenges, although also a potential for success (Ward \& Wolf-Wendel, 2012).

Later in my academic life in Kazakhstan, I began to hear similar comments as in the United States. Sometimes it was just an offhand comment, "oh! she's having another baby?!" while at other times it was more direct. It became clear that while there may be some new "rules" in living abroad at an international university, the overall sense of being a mother in academia was still precarious.

Returning to my office in those early days on campus, I realized I would need to make some changes as a mother. I was no longer at home, able to nurse my daughter on demand. Instead, as other mothers in the workplace, I was looking to find a schedule allowing me to either go home to feed the baby or find a location to pump milk. Should I just use the bathroom to express milk as I used to as a graduate student? It felt gross. Sitting in a stall, waiting for people to come and go, waiting for the smells to evaporate. I decided to try to turn my shared office into a place I could also use for pumping milk.

Looking around our office, I notice how my desk backed up against a large window facing other offices, and my colleagues' desk was across the room. Just then, my office mate-a young woman from Central Asia-walked in.

"Hi! What are you looking at?" she asked, noticing my furrowed brow examining the office space.

"I've been trying to figure out how to create a bit more privacy in here for pumping milk or nursing. This window is huge and right on eye level with everyone walking by. I wish someone would just add some frosting to it."

"Yeah, I totally agree. It is a bit like we are in a fishbowl, with people looking in all the time. It's totally natural to want to keep your body private."

After a few days of thinking about creating a more intimate space, I realized the simplest solution would be a stopgap one. "Do you mind if I put up paper on the windows to create a bit of privacy?"

She responded immediately and enthusiastically, "Of course not!"

And with that response, I added paper to the windows, creating frosted glass for privacy in pumping and nursing my daughter. It was a successful moment in developing a physical space as a mother in academia. I continued to think about the next steps and potential pushback - if someone would ask me to take it down, whether to put a sign on the door when I was occupied. Do I just lock the door? I could put a sign saying I'm busy, or perhaps testing the waters with a direct sign that outs me as a mother, PUMPING MILK-PLEASE COME BACK LATER. 


\section{Act III: A "Good" Academic}

How can I be "just" an academic when I also live on campus amidst public spaces and the hierarchy of academia? Is there a way to compartmentalize motherhood so I can maintain my "proper" image of an academic?

My husband turns to me and asks, "Do you want to go biking?" He is an avid bike rider who misses our regular family rides. Before we moved to Kazakhstan, we lived in Texas and would frequently ride as a family with just one toddler. Because of the warm weather, we could ride year-round. Our son would sit in the bright orange seat attached to my handlebars or in a yellow and orange trailer pulled from behind my husband's bike.

Now we are in Kazakhstan.

"Sure, let's go for a ride!" But my mind raced with thoughts of academic hierarchy I had learned in the United States. I kept thinking about what it meant to be seen with children as a mother and academic. During the day, I'm a scholar, lauded for my scholarly pursuits. But at night, if I am seen with my children, I will be seen as someone different. In the US, I remember how it felt to be talked down to suddenly or ignored once the academic world discovered I was a mother. For the academic mother, these dual roles carry expectations, responsibilities, and significance for professional and family life.

I took these American ideas with me when moving to Kazakhstan and immediately thought about what it would mean to be seen biking on campus, with children. How do I explain why I am not in my office? I bumped into the Provost last time I went walking on campus, will that happen again? What if I see my students? How can I maintain authority as their teacher when they see me in this other role? How do I show that I am still a professional? How will students see me differently? How do I maintain my role as a scholar when I'm being seen as a mother instead?

I realize now these questions were informed by the history of women in the workplace. Women have traditionally been excluded in many ways and today still do not earn close to the same wage as their male counterparts. Students, staff, and faculty did indeed see me differently once they saw my children. For some, I was elevated in status, a novel finding for myself compared to the United States. However, in other interactions, people avoided engaging with me and would give me a wide berth if they happened to see me with my children.

I prepared the bike with a child seat, a unique sight at that time in Kazakhstan, which meant everywhere I biked eyes turned to follow me. I prepared myself to perform in the role of mother and braced myself for interacting as an academic.

\section{Presentation of Self, Passing, and Covering}

At work, as long as I was not talking about my children or associated with an item to remind others of my motherhood status (e.g., stroller), I could "pass" as the ideal worker. Passing in this regard can be 
Performing, Passing, and Covering Motherhood in Academic Spaces: A Heartful Autoethnography

seen as a privilege (although not all agree, see Silvermint, 2018), or it could present other issues as a childless mother in an international context. For the University, the campus is family-friendly (CohenMiller et al., 2019). Still, academic mothers in Kazakhstan feel an ambiguity of gender and mother roles (Kuzhabekova, 2019), while graduate student mothers remain concerned about not having the needed policies or resources to succeed (CohenMiller, Saniyazova, \& Saniyazova, 2019; Saniyazova et al., 2020).

Presentation of self. Performance, and the ways individuals are seen, provide insight into how people are expected to behave and present themselves. In 1959, Erving Goffman wrote Presentation of Self, depicting everyday life as a stage, a performance on a daily basis. If every day is a performance, there are both actors and audiences involved. How we present ourselves-our performance-is interpreted by others whether we intend it or not. Using sociocultural theory (Vygotsky, 1978), as individuals, we interpret each other's embodied performances through our cultural lens. Thus, society and culture affect the way we see ourselves and others. The roles can change-employer, employee, parent, child-and the importance of how others see us, remains. Within the organizational setting of academia, each person tends to perform multiple roles, such as professor, committee member, colleague, or friend.

A presentation, or performance, of academic motherhood, can then be interpreted as "acting." Moreover, by focusing on one part of ourselves while compartmentalizing another can be considered fairly negatively: acting like someone else, acting up, two-face, to name a few examples. None of the phrases present a positive concept. Instead, they refer to being someone you are not, or behaving in a way not preferred. How do we reconcile the life as a stage with the negative connotation of performing on the stage?

However, for Goffman (1959), performance does not have to be negative. Instead, it is about everyday normal interaction. Using the theory of presentation of self, academic mothers might cover, choosing to downplay particular traits or "engage in 'face work' by not mentioning their children to others to present themselves as being only focused on their academic work" (CohenMiller, 2014a, 2014b)

Passing. Being associated with a category embodying your characteristics or identity can be referred to as "passing" (Goffman, 1963). The current use of the word "passing" frequently refers to "racial" passing. In racial passing, a person of one race passes intentionally, or through others' assumption, as another race (I use the term race in italics to emphasize its social construction). Passing has also been used to refer to those who pass as a particular gender, religion, social class, or as related to parenting status.

In several arenas of life, individuals may choose, or be considered, to "pass" as someone they are not. As Goffman explains (1963), passing can present significant assets: "Because of the great rewards in being considered normal, almost all persons who are in a position to pass will do so on some occasion by intent" (p. 74). In this scenario, Goffman suggests individuals may aim to deceive when it provides them benefits. However, passing can be determined both by the individual and also by others. Passing "...often occur[s] when an audience miscategorizes an individual's identity and prompts him or her to follow suit 
and embrace it" (Renfrow, 2019, p. 502). Related to passing as childfree, it can be a chance for silence or voice (Moore, 2018) and is a common occurrence.

In academia, mothers, especially graduate students who become mothers during their programs, are in a precarious position as an "outed" mother with limited resources and policies at the University-level. For instance, in my doctoral research with doctoral student motherhood and mothering, a participant confessed to having a "greatest fear," that she would be seen differently by her colleagues once becoming a mother, and found it essential to make "extra efforts to compensate" (CohenMiller, 2014b). Similarly, in another study of graduate student mothers, participants were concerned at "revealing their pregnancies and motherhood" (Williams, 2007, p. 103). Furthermore, the pressures mothers in academia experience are frequently mentioned (Evans \& Grant, 2008) and affect their well-being (CohenMiller \& Demers, 2019). These studies suggest the participants were struggling to fit the role of the ideal graduate student, one who is fully committed without outside responsibilities or tasks.

Covering. In addition to passing, Goffman (1963) also addressed the concept of "covering," a means to downplay a trait. Kenji Yoshino and Christie Smith (2013) explain the difference between covering and passing:

"Covering" differs from the more familiar term "passing." When an individual passes, she is ensuring that others around her do not know she possesses a particular identity. When an individual covers, she has disclosed that identity but seeks to mute its significance. Covering is a much more universal dynamic - while only some groups have the capacity to pass, all groups have the capacity to cover. (p. 4)

For those who are cannot cover their motherhood status in the academic workplace (e.g., being visibly pregnant, being seen with a child), they can face bias in interviews as well as negative pushback in the workplace (Carroll, 2018). Across higher education institutions in the United States, Kirsten Isgro and Mari Castañeda (2015) point to a consistent theme of "organizational prejudice and bias toward motherhood" (p. 174).

For mothers in academia, there may be a choice whether to cover motherhood status. If they are not visibly pregnant, mothers may be able to choose to avoid topics addressing children. On a superficial level, this constraint is simple and straightforward. Nevertheless, what happens when a work colleague asks to meet at the same time as childcare pickup (assuming the mother is picking up the child that day)?

\section{Act IV: Academic Hierarchy in the Wild}

The same day that I officially met the Dean in his office, I also later saw him in another context. This time, while he was still in his suit and tie, talking with colleagues, I was now in jeans and a T-shirt. I had already come home. I had already left the official premises of office life and entered into the realm of the family (Clark, 2000). While previously I had been wearing professional attire, in this encounter with my children, I was instead wearing informal athletic wear. I didn't have the air of academic confidence. I was out for a walk with my family, exploring the new sidewalks across campus. 
Our son, who was four at the time, was wearing his bright rubber boots and was chatting and running joyfully, looking for any puddles to jump in. Our five-month-old, attached securely to me with a thick grey baby carrier, cooed gently.

The Dean said hello, waving to my family and me as he walked by. My persona of academia no longer existed. Here I was, a mother. As an academic who studies motherhood in academia, I knew that the literature demonstrates how mothers in the workplace are devalued (Correll, 2013). And here I was, unexpectedly, reminded of my cultural framework suggesting I was devaluing myself. While I was being welcomed, I knew others were not, as evidenced by overhearing the following comment about a fellow colleague: "She should just stay home and take care of her children first."

"Hi," I said tentatively to the Dean, trying to find a way to hide. I felt flushed with emotion, my heartbeat heightened, and anxiety filling my ears, making it hard to hear. What had I just done? Had all my hard work to get to this position been for naught as now I've undone my professionalism with an informal interaction?

Later, I opened my email, looking forward to the first significant meeting of the semester. This was the meeting where we were supposed to be able to make effective changes to support students and faculty. Then I noticed the timing of the meeting. What? Really? The meetings all start at 5:30 pm?

I started thinking about how I could make it work. I was feeling what some academic mothers note as "a complex relationship regarding the (im)balance of family and work...with opposing forces of stress/sadness and support/love" (CohenMiller, 2016a). How I could go to both the meetings and also see my children in the evening, or more importantly, figure out how to pick them up from school. I wracked my brain, trying to come up with a solution. Really? Why does this have to be a choice? To either go to an important meeting or to be with my family? Doesn't the workday end by then?

Building up my courage, I talked to the organizers and pointed out the timing constraints the meeting may have on many people's lives. I didn't highlight my own challenge of childcare. I covered my motherhood status and instead talked about the broader community. Changing the timing of the meeting could help many faculty who have outside commitments. In changing the focus, I was able to engage more people. However, this change in discourse, unfortunately, minimized the experience of mothers by suggesting everyone else faces the same obstacles.

\section{Motherscholar: Intertwined Roles of Mother and Academic}

"The agency of the academic mother lies in her courage to rewrite and transform scholarship so that motherhood is written into her intellectualism, into her scholarship and into academia"

-Pillay, 2000, p. 513, emphasis added

Living as a mother in academia, in both the United States and for the last five years in Kazakhstan, has involved a constant internal narrative about performing, passing, and covering. Although in general 
it has been a very positive response, I have also been criticized directly and indirectly. Hearing someone say something negative about another mother-whether student, staff, or faculty—reminds me to be vigilant about the image I am portraying. It reminds me of the precarious position of mothers in general in the academic workplace, in particular those at the beginning of the academic pipeline. The occasional negative comments about a mother studying or working reminds me to continue to be aware of my positionality and the potential for push-back at any time. The international community at the University provides opportunities for thinking about ideas in varied ways, yet it also means that many of the "rules" of behavior aren't clearly identifiable.

On a larger scale, the history of women in society suggests a constant policing of women's and mother's behavior, and this doesn't change in academic spaces, even in supportive environments. Regardless of a generally increasing acceptance of women in the workplace in some societies and cultural contexts, the narrative of, what I'm calling, impermanent acceptance, requires constant work to remain aware of every interaction to assess the level of approval to vulnerability.

Yet, there is potential to make great change in academia for future generations. As a mother in academia, I am working to embrace each role and identity. As a "motherscholar," I can intentionally intertwine roles advocating against the bifurcated existence of each (Matias, 2011; The Motherscholar Project, 2020). I can demonstrate my position and stand up for others finding their place. It is a vulnerable position, yet easier now with children who don't need me as frequently. In this way, we can make changes to the historically ignored voices of women-and, by extension, mothers - to intentionally incorporate them into academic spaces (see CohenMiller \& Lewis, 2019).

As Green (2015) encourages, it is time to move "beyond assumptions and expectations of what constitutes good mothering'" (p. 196). By labeling and embracing, identifying, and seeing these multiple roles and performances as born from necessity, academic workspaces can move forward to acknowledge a place for within historically exclusionary institutions for motherscholars.

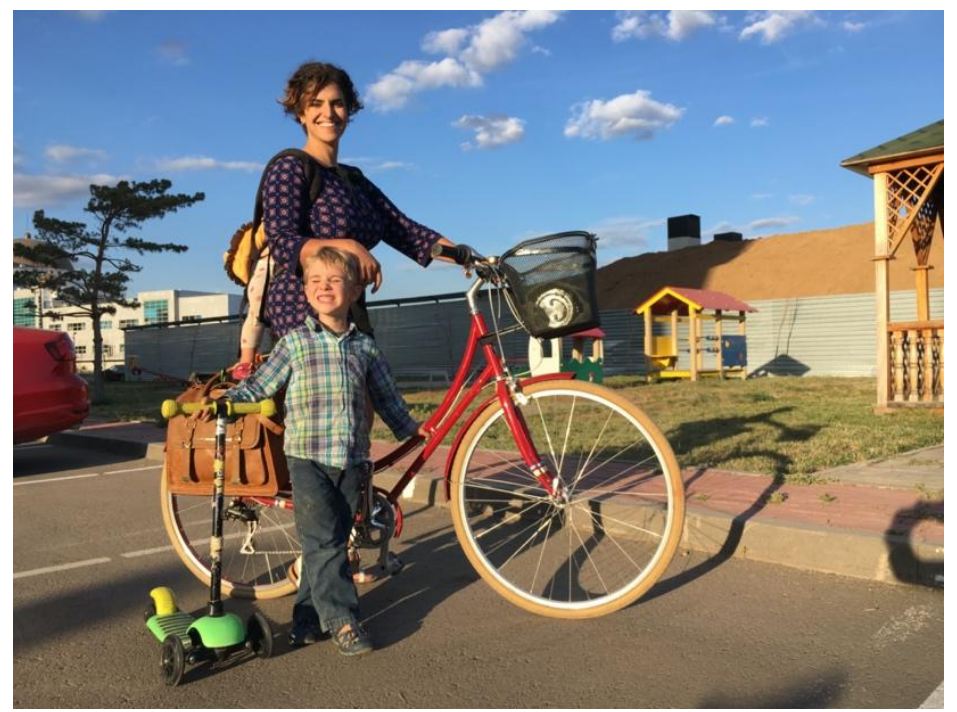

Fig. 1: The mother and academic: Motherscholar (Photo credit: Douglas CohenMiller) 


\section{Act V: Missing Opportunities}

At times I have decided to bring my children to academic events, purposively choosing to uncover my motherhood. I presented myself as a motherscholar, advocated on behalf of the mothers enrolled in the programs. Friday late afternoon came, and the smell of pizza began to waft down the hall. The graduate student team-building event was about to start.

I walked in confidently to a familiar space, with my two children by my side. Students surrounded the room in colorful, padded chairs. My kids jumped to a tall set of seats and began reaching for pizza immediately. Uh, maybe they should wait. I can feel everyone's eyes on me, and my children. Are their hands clean? Is the sauce dripping down on their clothes?

"You want the one with only cheese?" I asked my daughter. Then turning to face a student, "So, tell me about your thesis?"

Intercepting a small hand touching multiple pieces, "oh, you want another one?" then in the same breath, "Sounds great, tell me more about your work." For 20 minutes, I went back and forth, the dual identity and roles of motherscholar. Then the introductions to the faculty began.

"Hi everyone, I'm Dr. Anna CohenMiller, and I'm a qualitative methodologist who focuses on issues of social justice in education." I continued on to mention the programs I teach. But I left out the multiple years of studying women in academia, motherhood, and mothering. Even though I was looking at a room full of graduate students - the vast majority of women and many of them mothers - I continued to feel the internal pressure to cover (Goffman, 1963) this part of my work and life.

"Oh, and this is my family," I tacked on at the end, realizing I had completely left off a discussion of mothering in academia or my own children who were sitting next to me.

How could I do that? What did I just do?! I left off my own kids. I missed the opportunity to show them and the students in the room the importance and legitimacy of studying mothers in academia. I guess this was my effort to compartmentalize. Ugh.

I took a deep breath and turned to listen to the next person introducing themselves. I had performed the role of a "good" academic, but covered my motherhood status, unsuccessfully, and detrimentally.

\section{Act VI: The Costs of Being a Mother in Academia}

This article explored my experiences of performing as a mother in and out of academic spaces. For academic workspaces to address the needs of academic parents, there is a need to know how mothers are perceived. Research maintains a stigma exists for those who are mothers in the workplace (at least in Western contexts). 
No matter how much I try, as a mother in academia who lives on campus, I can't hide my motherhood status. I can't use the conventional technique of compartmentalizing work and home. Sometimes the world of academics merges with family life and vice versa. I've brought a child to class, to the office. At other times, while I'm out with my family, colleagues and I will bump into one another and start talking about work. The fine lines delineating one from another are less important from my perspective.

It's the evening now. Gathering helmets, I leave the house with the kids and bikes for a ride around campus. One child is on his bike, a little wobbly as he's perfecting riding on two wheels. I stay nearby, ready to help at any moment, taking on a mothering role. The other child sits in the grey bike seat directly behind me. She eagerly watches everything. I know she's watching me, learning from my actions and behaviors. I don't look the part of an academic. I'm not performing the role. I am no longer $100 \%$ focused on academic work. Instead, I have uncovered my role as a mother.

I still have those moments when I am reminded of the academic hierarchy. It can still be surprising to be mothering a child at the local coffee shop and having a student or top leader of the University come to say hi. Sociocultural indoctrination can be deep-seated. The messages sent about ideal workers and covering one's motherhood status can be pervasive.

Uh oh, they just saw me out of work! I should be at work.

But then I realize it's $7 \mathrm{pm}$ on a Tuesday or 9 am on a Saturday. Likewise, I have entered a different context. It's a space where motherhood doesn't have to be automatically downplayed but frequently prioritized. It's okay to not be at work. It's not typical work time. It's okay. I am an academic and a mother. I am a motherscholar.

I have uncovered my motherhood status in academia, but for others, the cost may be too high. These consequences of uncovering a motherhood status in academia need not exist. Until systematic bias can be addressed, we need to continually ask, what is the price of passing or uncovering oneself as a mother and what are we doing to eliminate this price?

\section{Coda: Performing Motherhood and Mothering in Academic Spaces}

Coming home from work, my kids met me outside, next to my bike.

"Oh, it looks like someone wants to go for a ride, yeah?" I say, smiling at both kids.

Without changing clothes or removing the briefcase from my bike, I start to get ready. I pick up my little one, putting her into a wrap for riding along with me on my bike.

"Faster Mama, faster!" calls my son, as he zooms ahead of me on his green scooter. Then he suddenly stops and asks to take a picture. We are now in front of a set of playgrounds on campus. Directly across from us are the academic buildings and a stream of people walking around. 
Performing, Passing, and Covering Motherhood in Academic Spaces: A Heartful Autoethnography

I am the motherscholar, but I still feel a bit conspicuous with children by my side. I know the research, which shows how children can be considered "props" to demonstrate good mothering, just based upon how they behave or what they wear (Collett, 2005). I try to talk myself into being okay with the academic world seeing me as a mother. I'm not covering (Goffman, 1963) my motherhood status. I'm embodying this role even though I'm unsure of the "spillover" of work and family (Clark, 2000).

"Todo bien, mi amor [Everything okay, sweetie]?" I ask my little one as she rearranges herself on my back. Then I look down to see what my son is wearing.

\section{References}

About us (2020). Nazarbayev University. Retrieved from https://nu.edu.kz/about-nazarbayev-university/history

Birken, S. A., \& Borelli, J. L. (2015, January 14). Coming out as academic mothers: What happens when two highly driven women in academe decide to have children? The Chronicle of Higher Education. Retrieved from https://www.chronicle.com/article/Coming-Out-as-Academic-Mothers/151157

Butler, J. (1993). Bodies that matter: On the limits of "sex." Routledge.

Carroll, T. (2018). The elephant (-sized belly) in the room. Journal of Humanistic Mathematics, 8(2), $127-142$.

Clark, S. C. (2000). Work/family border theory: A new theory of work/family balance. Human Relations, 53(6), 747-770. doi:10.1177/0018726700536001

CohenMiller, A. S. (2013). Motherhood in academia: A grounded theory pilot study of online texts. Educational Research: Theory and Practice (formerly, The Researcher), 25 (1), 47-66. Retrieved from http://www.nrmera.org/wp-content/uploads/2016/02/Researcherv25n1CohenMiller.pdf

CohenMiller, A. (2014a). The phenomenon of doctoral student motherhood/mothering in academia: Cultural construction, presentation of self, and situated learning. (Publication No. 3621085) [Doctoral dissertation, University of Texas at San Antonio]. Retrieved from https://pqdtopen.proquest.com/pubnum/3621085.html

CohenMiller, A. S. (2014b, April). Making doctoral student motherhood/mothering visible: Practical approaches for overcoming obstacles in academia. Presentation for Museum of Motherhood Conference, New York.

CohenMiller, A. S. (2016a). Artful research approaches in \#amwritingwithbaby: Qualitative analysis of academic mothers on Facebook. LEARNING Landscapes, 9(2) Special Issue, Artful Inquiry:

Transforming Understanding Through Creative Engagement, 9(2), 181-196.

doi.org/10.36510/learnland.v9i2.770

CohenMiller, A. S. (2016b). The mother-scholars' work-life integration. Retrieved from

https://www.insidehighered.com/blogs/university-venus/mother-scholars-work-life-integration

CohenMiller, A. S., \& Demers, D. (2019). Conflicting roles of mother and academic?: Exploring the use of arts-based self-care activities to encourage wellbeing. Art/Research International: A Transdisciplinary Journal. Retrieved from https://journals.library.ualberta.ca/ari/index.php/ari/article/view/29391 
CohenMiller, A. S., \& Lewis, J. (2019). Gender audit as research method for organizational learning and change in higher education. In Demos, V., Segal, M.and Kelly, K. (Eds.) Gender and Practice: Insights from the Field (Advances in Gender Research, Vol. 27; pp. 39-55). Emerald Publishing Limited.

CohenMiller, A. S., Sagitova, R. Ogay, S., Tselenko, Y., Shakhmanova, A., \& Saburova, A. (2019). What is a family-friendly campus? An exploratory study to develop student research and provide practical results. American Journal of Qualitative Research. Retrieved from http://www.ejecs.org/index.php/AJQR/article/view/170

CohenMiller, A. S., Saniyazova, A., \& Saniyazova, Z. (2019, April). Graduate student parents in Kazakhstan. Presentation for the Comparative International Education Society (CIES). San Francisco, CA.

Collett, J. L. (2005). What kind of mother am I? Impression management and the social construction of motherhood. Symbolic Interaction, 28(3), 327-347.

Collins, C. (2019). Making motherhood work: How women manage careers and caregiving. Princeton University Press.

Correll, S. (2013). Minimizing the motherhood penalty. Research Symposium: Gender \& Work: Challenging Conventional Wisdom. Harvard Business School. Retrieved from https://www.hbs.edu/faculty/conferences/2013-w50-research-symposium/Documents/correll.pdf

Ellis, C. (1999). Heartful autoethnography. Qualitative Health Research, 9(5), 669.

Ellis, C., Adams, T. E., \& Bochner, A. P. (2010). Autoethnography: An overview. Forum Qualitative Sozialforschung / Forum: Qualitative Social Research, 12(1). Retrieved from http://www.qualitativeresearch.net/index.php/fqs/article/view/1589/3095

Ellis, C., \& Bochner, A. (2016). Evocative autoethnography. Routledge.

Evans, E., \& Grant, C. (Eds.). (2008). Mama, PhD: Women write about motherhood and academic life. Rutgers University Press.

Goffman, E. (1959). Presentation of self in everyday life. Doubleday.

Goffman, E. (1963). Stigma: Notes on the management of spoiled identity. Simon \& Schuster.

Green, F. J. (2015). Re-conceptualising motherhood: reaching back to move forward. Journal of Family Studies, 21(3), 196-207.

Hays, S. (1996). The cultural contradictions of motherhood. Yale University Press.

History of the City (2020). Astana Government. Retrieved from http://astana.gov.kz/en/news/astanahistory/rubrics/206

Isgro, K., \& Castañeda, M. (2015). Mothers in US academia: Insights from lived experiences. Women's Studies International Forum, 53, 174-181.

Kazakhstan Population 2020. World Population Review (2020). Retrieved from http://worldpopulationreview.com/countries/kazakhstan-population/

Kim, J. Y., Fitzsimons, G. M., \& Kay, A. C. (2018). Lean in messages increase attributions of women's responsibility for gender inequality. Journal of Personality \& Social Psychology, 115(6), 974-1001. 
Performing, Passing, and Covering Motherhood in Academic Spaces: A Heartful Autoethnography

Kinser, A., Freehling, K., \& Hawkes, T. (2014). Introduction. In Kinser A., Freehling-Burton K., \& Hawkes T. (Eds.), Performing motherhood: Artistic, activist, and everyday enactments (pp. 1-14). Bradford, ON: Demeter Press. Retrieved from www.jstor.org/stable/j.ctt1 rrd9tv.4

Kuzhabekova, A. (2019). Performativity as cultural brokerage: An ethnographic exploration of the experiences of faculty mothers at an international university in Kazakhstan. Women's Studies International Forum, 75, 102250. doi:10.1016/j.wsif.2019.102250

Matias, C. (2011). "Cheryl Matias, PhD and Mother of Twins": Counter storytelling to critically analyze how I navigated the academic application, negotiation, and relocation process. Division G - Social Context of Education / Section 2. American Educational Research Association (AERA).

Modern Family Index 2018 (2019). Bright Horizons. Retrieved from https://www.brighthorizons.com/newsroom/modern-family-index-2018

Moore, J. (2018). From "I'm never having children" to motherhood: A critical analysis of silence and voice in negotiations of childbearing face. Women's Studies in Communication, 41(1), 1-21.

The Motherscholar Project (2020). Retrieved from www.motherscholar.org

NU At a Glance. (2020). Nazarbayev University. Retrieved from https://nu.edu.kz/about-nazarbayevuniversity/nu-at-a-glance

O'Reilly, A. (2017). Mothering against motherhood: The legacy of Adrienne Rich's of woman born. Women's Studies, 46(7), 728-729. doi:10.1080/00497878.2017.1363604

Pariona, A. (n.d.). Which countries border Kazakhstan? Kazakhstan border five other nations. World Atlas. Retrieved from https://www.worldatlas.com/articles/what-countries-border-kazakhstan.html

Pillay, V. (2009). Academic mothers finding rhyme and reason. Gender and Education, 21(5), 501-515. doi:10.1080/09540250802467927

Playing Room Opening Ceremony (2020, January 14). NU Magazine. Retrieved from https://magazine.nu.edu.kz/january2020/

Renfrow, D. G. (2019). A cartography of passing in everyday life. Symbolic Interaction, 27(4), 485-506. doi:10.1525/si.2004.27.4.485

Rich, A. (1976). Of woman born: Motherhood as experience and institution. W. W. Norton \& Company, Inc.

Sallee, M., Ward, K., \& Wolf-Wendel, L. (2016). Can anyone have it all? Gendered views on parenting and academic careers. Innovative Higher Education, 41(3), 187-202.

Sandberg, S. (2013). Lean in: Women, work, and the will to lead. Knopf.

Saniyazova, A., CohenMiller, A. S., \& Saniyazova, Z. (2020, April). Managing multiple roles: experiences of graduate student mothers in Kazakhstan. Presentation for Comparative International Education Society (CIES). Miami, Florida.

Shamshidinova, K., Ayubayeva, N., \& Bridges, D. (2014). Implementing radical changes: Nazarbayev Intellectual schools as agents of changes. In D. Bridges (Ed.), Educational reform and internationalisation: The case of school reform in Kazakhstan (pp. 71-82). Cambridge University Press. 
Silvermint, D. (2018). Passing as privileged. Ergo: An Open Access Journal of Philosophy, 5(1). doi:10.3998/ergo.12405314.0005.001

Villablanca, A. C., Beckett, L., Nettiksimmons, J., \& Howell, L. P. (2011). Career flexibility and family-friendly policies: An NIH-funded study to enhance women's careers in biomedical sciences. Journal of Women's Health, 20(10), 1485-1496.

Vik, T. A., \& DeGroot, J. (2019, November). "I don't let everyone see my struggles": Mothers' social support and privacy management. Peer-reviewed competitive paper presented at the convention of the National Communication Association.

Vygotsky, L. (1978). Mind in society: The development of higher psychological processes. Harvard University Press.

Ward, K., \& Wolf-Wendel, L. E. (2012). Academic motherhood: Managing work and family. Rutgers University Press.

White, M. A. (2016, April 28). Academia and motherhood; We can have both. The Washington Post. Retrieved from https://www.washingtonpost.com/news/grade-point/wp/2016/04/27/academia-andmotherhood-we-can-have-both/

Williams, J. C. (2005). The glass ceiling and the maternal wall in academia. New Directions for Higher Education, 2005(130), 91-105.

Williams, S. (2007). Graduate students/mothers negotiating academia and family life: Discourses, experiences, and alternatives. [Doctoral dissertation, University of South Florida, Tampa]. Retrieved from http://scholarcommons.usf.edu/etd/2412

Yoshino, K., \& Smith, C. (2013). Uncovering talent: A new model of inclusion. Deloitte University Center for Inclusion. Retrieved from https://www.dca.org.au/sites/default/files/06_uncoveringtalentpaper.pdf

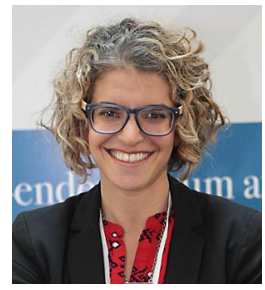

Anna S. CohenMiller has lived with her family in Kazakhstan for going on five years. As an Assistant Professor in the Graduate School of Education and Co-Director of The Consortium of Gender Scholars at Nazarbayev University, she uses arts-based methods and social media research to explore and examine the experiences of mothers in academia. Based upon her work, she developed The Motherscholar Project, an arts-based online awareness initiative to highlight the presence of mothers internationally. Anna is on the international advisory board for aKIDemic Life, an online hub for resources to support parents in academia, and welcomes collaborative ideas connecting research, educational practice, and community initiatives. 